\title{
Effects of Glyphosate on Isolated Maize Mitochondria
}

\author{
1. LÓPEZ-BRAÑA,A. DELIBES AND F. GARCÍA-OLMEDO \\ Departamento de Bioquimica, E.T.S. Ingenieros Agrónomos-UPM, Madrid-3, Spain
}

\begin{abstract}
The effects of the herbicide glyphosate $\left(\mathrm{K}^{+}\right.$salt) on isolated maize mitochondria have been investigated. Protein synthesis. oxygen uptake (state 3 and state 4 respiration) and passive swelling were inhibited at concentrations in the $10^{-6}-10^{-2} \mathrm{M}$ range. No decrease of the respiratory control ratio $(R C R)$ or stimulation of ATPase activity by glyphosate $\left(\mathrm{K}^{+}\right.$salt $)$were observed. It is concluded that the previously reported decrease of the $R C R$ and ATPase stimulation by glyphosate (isopropylamine salt) were probably due to the isopropylamine moiety or to impurities of the technical product.
\end{abstract}

Key words: Glyphosate; Herbicide action; Maize; Mitochondria.

\section{INTRODUCTION}

Glyphosate [ $N$-(phosphonomethyl) glycinel is a non-specific herbicide which has gained wide use because of its easy translocation within the plant and its ready inactivation and degradation in the soil. Hoagland and Duke (1982) have recently reviewed the biochemical effects of glyphosate on plants and have pointed out that although the interference of this herbicide with aromatic amino acid synthesis and phenolic compound metabolism is probably involved in its primary mechanism of action, other crucial process(es) might be equally affected. Respiration is among the processes which have been implicated in this context, but published evidence is somewhat contradictory. Ali and Fletcher (1978) reported that glyphosate was capable of inducing a dramatic and rapid decline in corn root respiration and concluded that the primary mode of action of the herbicide involves inhibition of respiration in roots resulting in death of the plant. They ascribed the previous report by Sprankle, Meggitt and Penner (1975) of a slower onset of respiratory inhibition to the fact that the latter authors had measured whole plant respiration, instead of the respiration of roots, which was the organ more markedly affected by the herbicide. Cole, Dodge and Casely (1980) also reported a rapid and complete impairment of respiratory competence in the roots, which was concomitant with the induction of phenylalanine ammonia-lyase. In contrast, other reports have indicated either no effect on respiration of roots (Hanson and Rieck, 1975; cited by Hoagland and Duke, 1982) and isolated cells (Brecke and Duke, 1980) or even an enhancement of respiration (Abu-Irmaileh, Jordan and Kumamoto, 1970). The only reported experiments carried out with isolated mitochondria (Olorunsogo, Bababunmi and Bassir, 1979 ) indicated an uncoupling of respiration in isolated corn-shoot mitochondria by the isopropylamine salt of the herbicide. However, the interpretation of these observations is obscured by the fact that the effect of herbicide dosage on respiratory uncoupling was erratic and by the reported evidence of the uncoupling effect of certain amines (Skulachev, Jasaitis, Navickaite, Yaguzhinsky, Liberman, Topaili and Zofina, 1969; cited by Dawson and Selwyn, 
1974). The present study is an investigation of the effects of glyphosate on mitochondria, which stemmed from the initial observation of an inhibition of mitochondrial protein synthesis by pure glyphosate.

\section{MATERIALS AND METHODS Glyphosate}

The acid form (96.7\% pure), kindly supplied by Monsanto (Spain), was used throughout this study as a $100 \mathrm{~mol} \mathrm{~m}^{-3}$ stock solution which was brought to $\mathrm{pH} 7.2$ with $\mathrm{KOH}$. When indicated in the text, a concentrated solution of the isopropylamine salt $\left(460 \mathrm{~g} \mathrm{dm}^{-3}\right)$, or its commercial formulation, 'Round Up', ( $360 \mathrm{~g} \mathrm{dm}^{-3}$ plus surfactant), were also used.

\section{Preparation of mitochondria}

Zea mays L., hybrid stock G-4507 (Mahissa, Spain) was germinated in the dark for about $\mathbf{4} \mathrm{d}$ and mitochondria were isolated essentially as described by Forde, Oliver and Leaver (1979). About $16 \mathrm{~g}$ of hand-dissected coleoptiles were homogenized in 2 vols of $0.4 \mathrm{~mol} \mathrm{dm}^{-3}$ mannitol, $8.0 \mathrm{~mol} \mathrm{~m} \mathrm{~m}^{-3}$ cysteine, $0 \cdot 1 \%(w / v)$ bovine serum albumin (BSA), $1.0 \mathrm{~mol} \mathrm{~m}{ }^{-3}$ EGTA, $10 \mathrm{~mol} \mathrm{~m}^{-3} \mathrm{MOPS}$. brought to $\mathrm{pH} 7.8$ with $\mathrm{KOH}$. The mitochondria in the homogenate were pelleted between $1000 \times g$ and $10000 \times g$ and further purified by sucrose gradient centrifugation $\left(10 \%-55 \%\right.$, w/w, sucrose in $1.0 \mathrm{~mol} \mathrm{~m}^{-3} \mathrm{EGTA}$,

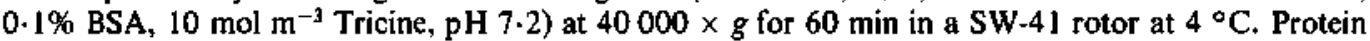
was quantitated by the method of Bradford (1976).

\section{Protein synthesis by isolated mitachondria}

The procedure described by Forde, Oliver and Leaver (1978) was followed throughout, except that $2 \%$ cycloheximide (Forde et al., 1979) was used in the incubation media. Mitochondria (80-250 $\mu \mathrm{g}$ of protein) were incubated with vigorous shaking in $70 \mathrm{~mm}^{3}$ of a medium containing $0.26 \mathrm{~mol} \mathrm{dm}^{-3}$ mannitol, $90 \mathrm{~mol} \mathrm{~m} \mathrm{~m}^{-3} \mathrm{KCl}, 10 \mathrm{~mol} \mathrm{~m}^{-3} \mathrm{MgCl}_{2}, 10 \mathrm{~mol} \mathrm{~m}^{-3}$ Tricine (pH 7.2), 5.0 mol m $\mathrm{m}^{-3}$ sodium

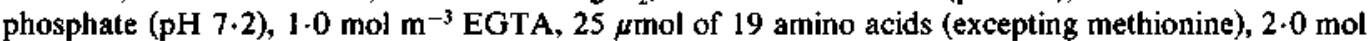
$\mathrm{m}^{-3}$ dithiothreitol, $1.0 \mathrm{~mol} \mathrm{~m}{ }^{-3} \mathrm{GTP}$, and $5.0 \mu \mathrm{Ci}$ of $\left[{ }^{35} \mathrm{~S}\right]$ methionine $\left(800 \mathrm{Ci} \mathrm{mmol}^{-1}\right)$. Aliquots of $3.0 \mathrm{~mm}^{3}$ were counted after precipitation with cold $10 \%$ trichloroacetic acid in a liquid scintillation counter (Intertechnique). Incubations were carried out for $60 \mathrm{~min}$ at $25^{\circ} \mathrm{C}$. Energy was provided either by the inclusion of $10 \mathrm{~mol} \mathrm{~m}^{-3}$ sodium succinate $/ 6.0 \mathrm{~mol} \mathrm{~m}^{-3}$ ADP or $8.0 \mathrm{~mol} \mathrm{~m}^{-3}$ creatine phosphate $/ 25 \mu \mathrm{g}$, creatine phosphokinase $/ 6.0 \mathrm{~mol} \mathrm{~m}^{-3}$ ATP. The initial inhibition experiment was carried out with a commercial formulation of glyphosate (isopropylamine salt, surfactant included). All subsequent experiments were performed with pure glyphosate $\left(\mathrm{K}^{+}\right.$salt). After incubation, the samples were fractionated by sodium dodecyl sulphate-polyacrylamide gel electrophoresis (SDS-PAGE; $12.5 \%$ acrylamide) according to Laemmli (1970). Fluorography of the labelled proteins was carried out according to Laskey and Mills (1975).

\section{Measurements of respiratory activity}

Oxygen uptake was measured in a Clarke electrode. Purified mitochondria were resuspended in a

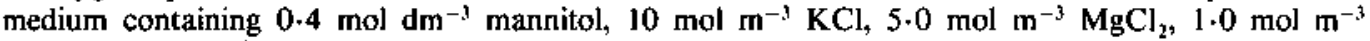
EGTA, $0.1 \%(w / v)$ BSA, $0.8 \mathrm{~mol} \mathrm{~m}^{-3}$ ATP, $10 \mathrm{~mol} \mathrm{~m}^{-3} \mathrm{~K}$-phosphate, $\mathrm{pH} 7.2$, and $10 \mathrm{~mol} \mathrm{~m}^{-3}$ succinate as substrate. Effects on state 4 respiration were measured by addition of the test chemical following ADP depletion during the period of state 3 respiration initiated by the addition of a limited amount of ADP $(0.2 \mu \mathrm{mol})$. The effect on state 3 respiration was determined by adding the test chemical after an excess of ADP $(1.0 \mu \mathrm{mol})$. Respiratory control ratios for $\mathrm{O}_{2}$ utilization were determined from the oxygen-electrode traces recorded in response to ADP additions.

\section{ATPase activity}

The assay was carried out according to McMurray and Begg (1959), as described by Bababunmi and Bassir (1972). The incubation medium was $0.108 \mathrm{~mol} \mathrm{dm}{ }^{-3}$ sucrose, $75 \mathrm{~mol} \mathrm{~m}^{-3} \mathrm{KCl}, 50 \mathrm{~mol} \mathrm{~m}^{-3}$ Tricine, at either $\mathrm{pH} 7.4 \mathrm{or} \mathrm{pH} 8.5$. Mitochondria ( $\sim 600 \mu \mathrm{g}$ of protein) were incubated in a volume of $200 \mathrm{~mm}^{3}$ for $20 \mathrm{~min}$, at $20^{\circ} \mathrm{C}$. The reaction was stopped by adding $2 \% \mathrm{H}_{2} \mathrm{SO}_{4}, 0.5 \% \mathrm{SDS}$. The phosphate liberated was quantified by its colour reaction with $0.5 \%$ ammonium molybdate (absorbance at $750 \mathrm{~nm}$ ). 


\section{Swelling and contraction of mitochondria}

The mitochondrial suspension was transferted to the swelling medium $\left(0.2 \mathrm{~mol} \mathrm{dm}^{-3} \mathrm{KCl}, 20 \mathrm{~mol}\right.$ $\mathrm{m}^{-3}$ Tricine buffer, $\mathrm{pH} 7.5$. and $0.1 \%$ BSA) and passive swelling was measured spectrophotometrically by the changes in light-scattering at $520 \mathrm{~nm}$. as described by Stoner and Hanson (1966). Test chemicals were added as indicated in Fig. 4. Contraction was induced by addition of 1.0

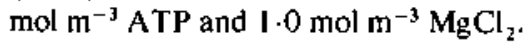

\section{RESULTS}

Protein synthesis by isolated corn-shoot mitochondria was inhibited by very low concentrations of a commercial glyphosate preparation (isopropylamine salt plus surfactant), as shown in Fig. I. To ascertain that the observed effect was due to glyphosate, and not to the amine or the surfactant, the acid form of the herbicide was brought up to $\mathrm{pH} 7.2$ with $\mathrm{KOH}$ and added to the incubation mixture at different concentrations, the amount of $\mathrm{K}^{+}$contributed in this way being negligible in comparison with the $\mathrm{K}^{+}$concentration $\left(10^{-1} \mathrm{~mol} \mathrm{dm}^{-3}\right)$ of the incubation media. Protein synthesis was inhibited both when supported by an external energy source (creatine phosphokinase/creatine phosphate) and when energy was supplied by succinate respiration (Fig. 1). The inhibition with the $\mathrm{K}^{+}$salt was less pronounced than with the commercial formulation. An enhancement of protein synthesis was observed at $10^{-2} \mathrm{~mol}$ $\mathrm{dm}^{-3}$ glyphosate in the case of the succinate-mediated synthesis, which was consistent over several experiments, although its magnitude was variable. Protein patterns after electrophoresis and fuorography were essentially the same as those reported by Forde et al. (1978, 1979) and the inhibition by glyphosate affected all the observed proteins in a similar way (results not shown).

Glyphosate $\left(\mathrm{K}^{+}\right.$salt) was found to inhibit oxygen consumption both in state 4 (ADP absent from the medium) and in state 3 (excess ADP in the medium) of respiration (Fig. 2A). This inhibition increased with concentration, but was not complete even at $10^{-2} \mathrm{~mol} \mathrm{dm}^{-3}$



FIG. 1. Inhibition by glyphosate of protein synthesis by isolated maize mitochondria. Mitochondria $\left(80-250 \mu \mathrm{g}\right.$ of protein) were incubated with $5.0 \mu \mathrm{Ci}$ of ${ }^{35} S \mid$ methionine $\left(800 \mathrm{Ci} \mathrm{mmol}^{-1}\right)$ in a final volume of $70 \mathrm{~mm}^{3}$. Two $3.0 \mathrm{~mm}^{3}$ aliquots were taken for counting and the rest was used for electrophoresis and fluorography. $\left(-\boldsymbol{\Lambda}_{-}-\right)$Pure glyphosate $\left(\mathrm{K}^{+}\right.$salt $)$, creatine phosphate/creatine kinase as energy source, $100 \%=50000 \mathrm{ct}$. $\mathrm{min}^{-1}(-\mathrm{O}-\mathrm{O}-)$ Pure glyphosate $\left(\mathrm{K}^{+}\right.$salt), succinate as energy source, $100 \%=9500 \mathrm{ct} \cdot \mathrm{min}^{-1}(-\mathrm{-}-)$ Formulated product (isopropylamine salt plus surfactant), creatine phosphate/creatine kinase as energy source. $100 \%=17500 \mathrm{ct} . \mathrm{min}^{-1}$. Controls with acetate as energy source yielded $<10 \%$ of the insoluble ct. $\min ^{-1}$ obtained with succinate. 

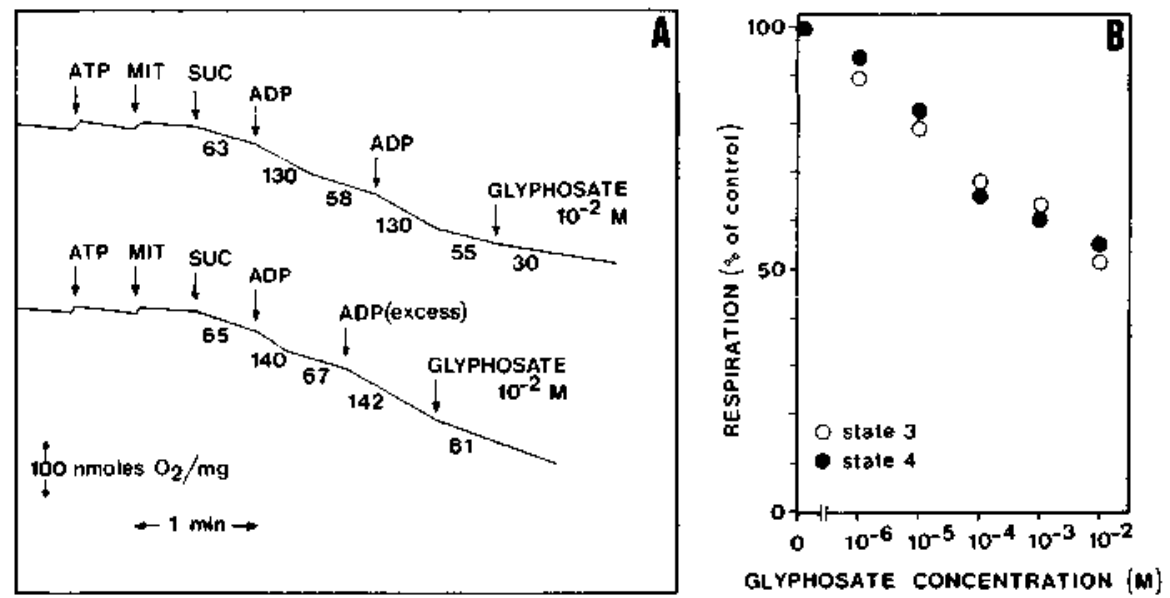

FIG. 2. Effect of glyphosate $\left(\mathrm{K}^{+}\right.$salt) on respiration of isolated mitochondria (A) Oxygen electrode traces corresponding to state 4 (upper trace) and state 3 (lower trace) respiration. The following additions were made to a $2.5 \mathrm{~cm}^{3}$ electrode chamber: $2.0 \mu \mathrm{mol}$ ATP. $400 \mu \mathrm{g}$ (state 4) and $800 \mu \mathrm{g}$ (state 3) mitochondrial protein (MIT). $23 \mu \mathrm{mol}$ succinate (SUC). $200 \mathrm{mmol}$ ADP or $1.0 \mu \mathrm{mol}$ ADP (excess). numbers under the traces indicate nmol of $\mathrm{O}, \mathrm{min}^{-1} \mathrm{mg}^{-1}$. (B) Variation of inhibition with glyphosate concentration.

(Fig. 2B). Respiratory inhibition was similar in both states and the respiratory control ratio $(R C R)$ was not significantly affected. In a separate experiment, the $\mathrm{K}^{+}$salt and the isopropylamine salt (without surfactant) were compared at a concentration of $10^{-3} \mathrm{~mol} \mathrm{dm}^{-3}$ and while the $\mathrm{K}^{+}$salt did not affect the $R C R(<5 \%)$, the isopropylamine salt markedly decreased the $R C R$ (about $38 \%$ ). No significant enhancement of ATPase activity by glyphosate ( $\mathrm{K}^{+}$salt) was observed either at $\mathrm{pH} 7.4$ or at $\mathrm{pH} 8.5$ (Table 1).

Corn mitochondria undergo swelling in the presence of $\mathrm{KCl}$. A significantly slower rate of swelling is observed when glyphosate $\left(\mathrm{K}^{+}\right.$salt) is added to the medium (Fig. $3 \mathrm{~A}$ ) and this effect is concentration dependent (Fig. 3B). Glyphosate ( $\mathrm{K}^{+}$salt)-treated mitochondria are still able to contract when ATP- $\mathrm{Mg}^{2+}$ is added (Fig. $3 \mathrm{C}$ ). Oligomycin also retards swelling, but dinitrophenol (DNP) accelerates the process (Fig. 3D). The isopropylamine salt of glyphosate has the same slowing effect, on a molar basis, as the $\mathrm{K}^{+}$salt. but prevents the contraction mediated by ATP-Mg ${ }^{2+}$ (Fig. 3E), a situation which is similar to that of oligomycin (Fig. 3D). The experiment in Fig. $3 \mathrm{~F}$ was carried out to ascertain that glyphosate retards the swelling of mitochondria but does not induce contraction.

TA В LE 1. Effect of glyphosate on ATPase activity

\begin{tabular}{|c|c|c|}
\hline \multirow{2}{*}{$\begin{array}{l}\text { Glyphosate (K' salt) } \\
\text { (mol dm ") }\end{array}$} & \multicolumn{2}{|c|}{ Activity ( $\left.\mathrm{nmol} \mathrm{mg}{ }^{\prime} \min { }^{\prime}\right)$ ' } \\
\hline & $\mathrm{pH} 7.4$ & $\mathrm{pH} 8.5$ \\
\hline $\begin{array}{c}0 \\
10^{4} \\
10^{3}\end{array}$ & $\begin{array}{l}52 \\
54 \\
57\end{array}$ & $\begin{array}{l}59 \\
54 \\
63\end{array}$ \\
\hline
\end{tabular}

"Average of 3 determinations. Phosphate liberated in $20 \mathrm{~min}$ at $20^{\circ} \mathrm{C}$ was measured in an incubation mixture of $200 \mathrm{~mm}^{3}$ containing about $600 \mu \mathrm{g}$ of protein. 

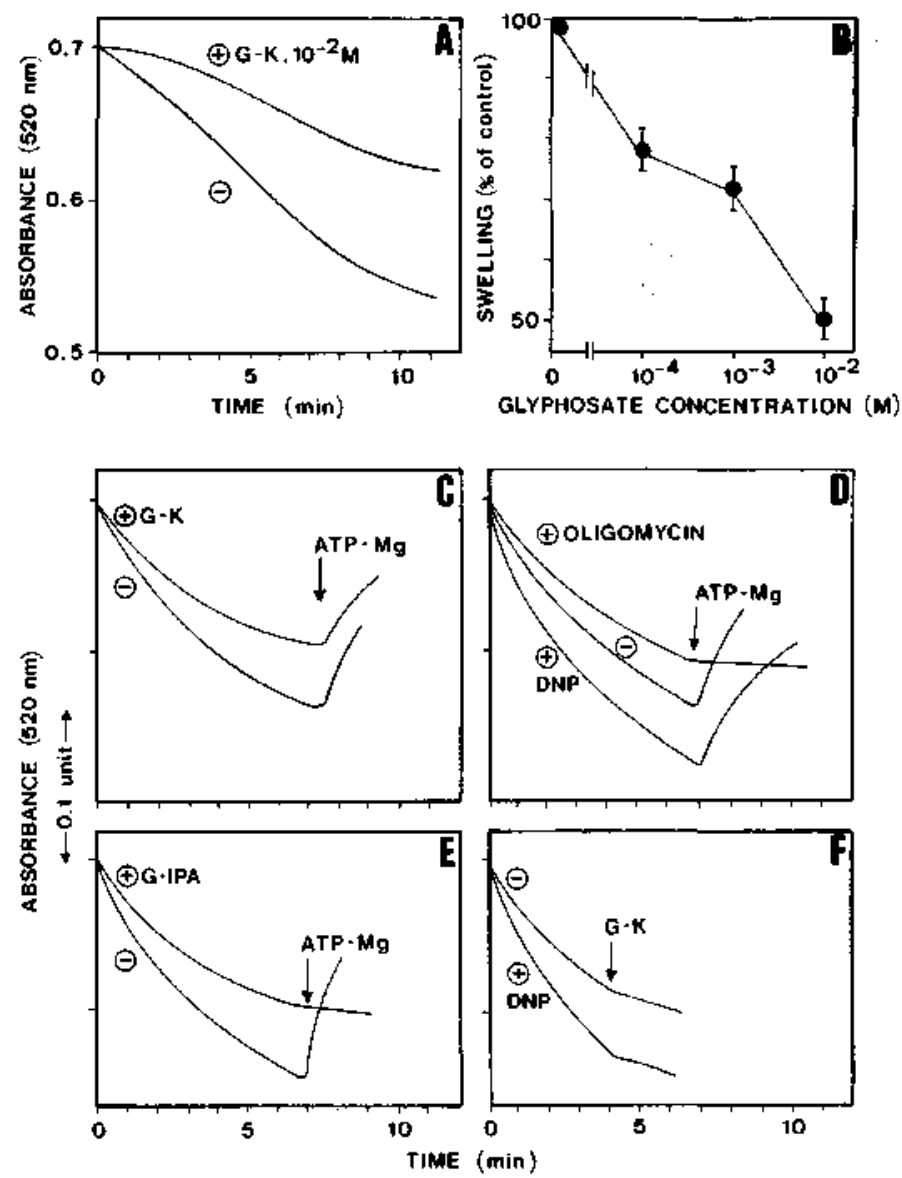

FIG. 3. Effect of glyphosate on passive swelling of mitochondria $\left(90-120 \mu \mathrm{g} \mathrm{cm}^{-3}\right)$. (A) Effect of initial addition of glyphosate ( $\mathrm{K}^{+}$salt: $\mathrm{G}-\mathrm{K}$ ). (B) Dosage dependence of swelling inhibition by $\mathbf{G}-\mathrm{K}: 100 \%$ swelling $=0.16 \mathrm{Abs} / 10 \mathrm{~min}$. (C) Contraction mediated by $\mathrm{ATP}-\mathrm{Mg}^{2+}$ in the presence $\left(5 \times 10^{-3} \mathrm{~mol}\right.$ $\left.\mathrm{dm}^{-3}\right)$ and in the absence of $\mathrm{G}-\mathrm{K}$. (D) Effects of oligomycin $\left(1.0 \mu \mathrm{g} \mathrm{cm}^{-3}\right)$ and dinitrophenol $\left(10^{-4} \mathrm{~mol}\right.$ $\mathbf{d m}^{-3}$. DNP). (E) Elfect of glyphosate (isopropylamine salt. G-IPA). (F) Effect of late addition of G-K.

\section{DISCUSSION}

The present evidence confirms that glyphosate markedly affects plant mitochondria, but indicates that the uncoupling effects reported by Olorunsogo et al. (1979) for the isopropylamine salt of glyphosate were probably due either to the isopropylamine moiety or to impurities. Indeed, we did not observe either a decrease of the $R C R$ or a stimulation of ATPase when the $\mathrm{K}^{+}$salt of glyphosate was used in the presence of excess $\mathrm{KCl}$ in the medium. In our experiments, the isopropylamine salt did decrease the $R C R$ but its effect on mitochondrial swelling was opposite to that of dinitrophenol, which is a typical uncoupler. The effects of the $\mathrm{K}^{+}$and the isopropylamine salts on mitochondrial swelling were identical, except that the latter prevented ATP-mediated mitochondrial contraction.

The three observed effects, inhibition of respiration, inhibition of protein synthesis, and retardation of mitochondrial swelling, could be explained in terms of a single mechanism because the alteration of membrane permeability could result in a limitation of the access of the amino acid precursors and the respiratory substrate into the mitochondria or in an alteration of the internal concentrations of ions. However, the present evidence does not exclude the possible independence of the different effects. The creatine phosphokinase/ 
creatine phosphate energy-generating system is not affected by glyphosate as evidenced by the lack of effect of glyphosate on in vitro protein synthesis by the wheat-germ system supported by the same energy source (unpublished results). We have no obvious explanation for the observed enhancement of protein synthesis at $10^{-2} \mathrm{~mol} \mathrm{dm}-3$ glyphosate.

Glyphosate effects on isolated mitochondria are detected at concentrations as low as $10^{-6}$ to $10^{-4} \mathrm{~mol} \mathrm{dm}^{-3}$, which indicates that these organelles are at least as sensitive to the herbicide as other well studied targets. Thus, the induction of phenylalanine ammonia-lyase in maize seedlings occurs at $10^{-4}$ to $10^{-3} \mathrm{~mol} \mathrm{\textrm {dm } ^ { - 3 }}$ glyphosate (Hoagland and Duke, 1982); depression of anthocyanin synthesis in excised hypocotyls of buckwheat is detected at $10^{-6}$ $\mathrm{mol} \mathrm{dm}^{-3}$ while inhibition of chlorophyll synthesis takes place only at concentrations above $10^{-5} \mathrm{~mol} \mathrm{dm}^{-3}$ (Holländer and Amrhein, 1980); the conversion of shikimate to anthraquinones is blocked in $G$. mollugo cell cultures at concentrations above $10^{-4} \mathrm{~mol} \mathrm{dm}^{-3}$ (Amrhein, Brigette, Gehrke and Steinrücken, 1980). However, it should be pointed out that direct comparison of results among different reports is difficult because of two reasons: (i) different glyphosate preparations have been used (pure acid or isopropylamine salt, with or without surfactant) and (ii) there is lack of knowledge of the intracellular glyphosate levels attained in each case. Brecke and Duke (1980) showed that glyphosate was quickly absorbed by whole bean plants but not by individual leaf cells. It would be of interest to investigate whether different types of plant cells have different permeabilities to the herbicide.

\section{ACKNOWLEDGEMENTS}

We wish to acknowledge the gift of the glyphosate samples by Dr J. Costa (Monsanto, Spain) and advice on the ATPase assay by Dr R. Serrano.

\section{LITERATURE CITED}

Abu-IrmaileH, B. E., JoRdan, L. S., and Kumamoto. J., 1970. Enhancement of $\mathrm{CO}_{2}$ and ethylene production and cellulase activity by glyphosate in Phaseolus vulgaris. Weed Science, 27, 103-6.

ALl, A., and Fletcher. R. A., 1978. Phytotoxic action of glyphosate and amitrole on corn seedlings. Canadian Journal of Botany, 56, 2196-202.

Amrhein, N., Brigette, D., Gehrke, P.. and Steinrücken. H. C., 1980. The site of the inhibition of the shikimale pathway by glyphosate. II Interference of glyphosate with chorismate formation in vivo and in vitro. Plant Phisiolog.', 66, 830-4.

Bababunmi, E. A., and Bassir, O.. 1972. Effects of aflatoxin $B_{1}$ on the swelling and adenosine triphosphatase activities of mitochondria isolated from different tissues of the rat. FEBS Letters. 26, 102-4.

BRADFORD. M. M.. 1976. A rapid and sensitive method for the quantitation of microgram quantities of protein utilizing the principle of protein-dye binding. Analytical Biochemistry. 72, 248-54.

BRECKE, B. J., and DUKE, W. B., 1980. Effects of glyphosate on intact bean plant (Phaseolus vulgaris L.) and isolated cells. Plant Physiologv, 66, 656-9.

Cole, D. J., Dodge, A. D., and CASELY, J. C., 1980. Some biochemical effects of glyphosate on plant meristems. Journal of Experimental Botany, 31, 1665-74.

Dawson, A. P.. and SELWYN, M. J.. 1974. Mitochondrial oxidative phosphorylation. In Companion to biochemistry. Selected topics for further study. Eds A. T. Bull. J. R. Lagnado. J. O. Thomas and K. F. Tipton. Longman Group Limited. London. Pp. 553-86.

FORDE, B. G., OLIVER, R. J., and LEAVER, C. J.. 1978. Variation in mitochondrial translation products associated with male-sterile cytoplasms in maize. Proceedings of the National Academy of Sciences (U.S.A.) 75, 3841-5.

- -1979 . In vitro study of mitochondrial protein synthesis during mitochondrial biogenesis in excised plant storage tissue. Plant Physiology, 63, 67-73.

HaNSON, C. L., and Rieck, C. E., 1975. Effect of glyphosate on respiration. Proceedings of the South African Weed Science Society, 28, 297-301.

HoAGLAND, R. E., and DUKE, S. O., 1982. Biochemical effects of glyphosate ( $N$-(phosphonomethyl) glycinel. In Biachemical responses induced by herbicides. Symposium Series 181. Eds D. E. 
Moreland, J. St. John, and F. D. Hess. American Chemical Society, Washington, D.C. Pp. 175-205.

HOlläNDER, H., and AMrhein, N., 1980. The site of the inhibition of the shikimate pathway by glyphosate. I. Inhibition by glyphosate of phenyl propanoid synthesis in buckwheat (Agropyron esculentum Moench.). Plant Physiology, 66, 823-9.

LAEMMLI, U. K., 1970. Cleavage of structural proteins during the assembly of head of bacteriophage T4. Nature, 227, 680-5.

LASKeY, R. A., and Mills, A. D., 1975. Quantitative film detection of ${ }^{3} \mathrm{H}$ and ${ }^{14} \mathrm{C}$ in polyacrylamide gels by fluorography. European Journal of Biochemistry, 56, 335-41.

McMurraY, W. C., and BegG. R. W., 1959. Effect of valinomycin on oxidative phosphorylation. Archives of Biochemistry and Biophysics, 84, 546-8.

Olorunsogo, O. O., Bababunmt, E. A., and Bassir, P., 1979. Uncoupling of corn shoot mitochondria by $N$-(phosphonomethyl) glycine. FEBS Letters, 97, 279-82.

Skulachev, V. P., Jasaitis, A. A., Navickaite, V. V., Yaguzhinsky, L. S., Liberman, E. A., TOPAILI, V. P., and ZoFinA, L. M., 1969. Five types of uncouplers for oxidative phosphorylation. In Mitochondria structure and function. Eds L. Enster and Z. Drahota. FEBS Symposium, Volume 17. Academic Press, London and New York. Pp. 275-84.

Sprankle, P.. Meggitt, W. F., and Penner, D., 1975. Absorption, action and translocation of glyphosate. Weed Science, 23, 235-40.

Stoner, C. D., and HANSON, J. B., 1966. Swelling and contraction of corn mitochondria. Plant Physiology, 41, 255-66. 